FACTA UNIVERSITATIS

Series: Law and Politics Vol. 16, N 2, 2018, pp. 109-120

https://doi.org/10.22190/FULP1802109M

Original Scientific Paper

\title{
SPECIAL MEASURES FOR PREVENTING THE COMMISSION OF SEX CRIMES AGAINST MINORS: THE EXAMPLE OF SERBIA*
}

UDC 343.541(497.11)

\section{Dušica Miladinović-Stefanović, Saša Knežević}

\author{
Faculty of Law, University of Niš, Serbia
}

\begin{abstract}
The Convention on the Protection of Children against Sexual Exploitation and Sexual Abuse (2007) was ratified and thus incorporated into the Serbian legal system in 2010 , which entailed the obligation to regulate this matter in greater detail by introducing specific measures aimed at preventing this type of criminal activity. This aim was accomplished by adopting the Act on Special Measures for Preventing the Commission of Sex Crimes against Minors (2013). This paper explores the aforementioned special measures for preventing sexual abuse of children, with particular reference to some controversial and disputable issues.
\end{abstract}

Key words: sexual offences, minors, special measures for preventing sex crimes against minors.

\section{INTRODUCTORY REMARKS}

The results of recent studies in the area of sex crimes against minors are rather alarming, stating that one out of five children in Europe is affected by some kind of sexual violence/abuse. ${ }^{1}$ The national studies also demonstrate a disturbing fact that this type of criminal activity is fairly common and widespread in Serbia, which may be

Received November $20^{\text {th }}, 2018 /$ Accepted November $22^{\text {nd }}, 2018$

Corresponding author: Assist. Prof. Dušica Miladinović-Stefanović, LL.D., Faculty of Law, University of Niš, Trg kralja Aleksandra 11, 18000 Niš, Republic of Serbia

E-mail: dusica@prafak.ni.ac.rs

${ }^{*}$ The paper discusses the results of the research study conducted within the project "Harmonization of the Serbian legislation with the EU law”, financially supported by the Faculty of Law, University of Niš, in the period from 2013 to 2018 . This paper was presented at International conference "Contemporary challenges to the criminal legislation" (on the occasion of the $50^{\text {th }}$ anniversary of the Bulgarian Criminal code from 1968), held on $8-9^{\text {th }}$ May at Sofia university "St. Kliment Ohridski", Sofia, Bulgaria.

1 This fact is the result of various studies conducted in many EU countries, UNICEF and World Health Organization statistical data. More information is available in the documents pertaining to the Council of Europe campaign One in Five: The Council of Europe Campaign to Stop Sexual Violence Against Children, accessible at http://www.coe.int/t/DG3/children/1in5/default_en.asp, accessed on April $8^{\text {th }}, 2018$. 
illustrated by the fact that as many as $68 \%$ of child-victims of human trafficking in Serbia have been primarily aimed at sexual exploitation, whereas one out of three young girls has been exposed to some kind of sexual abuse before the age of eighteen. ${ }^{2}$ The frequency of this phenomenon, its evolution and development of new models due to the abuse of information technologies, transnational presence and detrimental effects on children's health and their psycho-social development are the reasons why the Council of Europe adopted the Convention on the Protection of Children against Sexual Exploitation and Sexual Abuse in 2007 (hereinafter: the Convention). ${ }^{3}$ The Convention was ratified and thus incorporated into the Serbian legal system, ${ }^{4}$ which entailed the obligation to revise the national legal framework and introduce various measures envisaged in the Convention. This was accomplished by adopting the Act on Special Measures for Preventing the Commission of Sex Crimes against Minors (hereinafter: the Special Measures Act). ${ }^{5}$ This Act is to be regarded not only as a response to the accepted international obligations but also within the framework of a broader social action outlined in the National Strategy for the Prevention and Protection of Children against Violence (2008). ${ }^{6}$

For the purpose of preventing and counteracting sex crimes against minors, the Special Measures Act envisaged a very complex mechanism comprising several legal instruments, such as: prohibition of mitigating the imposed punishment, prohibition of release on parole, preclusion on the statute of limitations on criminal prosecution and execution of punishment (Article 5); legal consequences of the conviction (Article 6); special measures (Articles 7 12); and keeping criminal records on the convicted sex offenders (Articles $13-15$ ). In foreign theory, these measures are known as post-incarceration sanctions, and their introduction was based on the assessment that the existing criminal sanctions for such offences were not effective enough, so that the post-penal treatment of a perpetrator (in the broadest sense) emerged as a very significant factor in the fight against criminal recidivism (Wright, 2008: 17). Generally speaking, regardless of their potential heterogeneity, the measures taken after the release of the convicted offender always have a common goal: to control, supervise and provide assistance to the offenders, and thus reduce the risk of recidivism, reoffending by committing the same or similar criminal act for which they have already been convicted. As the Convention does not propose any particular guidelines considering the aforementioned preventive measures, the national legislator was free to devise and develop this system in line with the observed needs. Thus, the Serbian legislator enacted the following preventive measures: the obligation of the convicted sex offenders to periodically report to the competent police authority and the Directorate for the Execution of Criminal Sanctions; the ban on visiting places where minors commonly gather for educational, recreational or social purposes; mandatory counseling in professional counseling centers and institutions; mandatory notification of any change concerning the place of residence, habitual stay or

\footnotetext{
${ }^{2}$ The results of national studies are based on the discussions by Petković, N., Đorđević, M., Balos, Đ., in Analiza stavova javnosti u Srbiji prema fenomenu seksualne zloupotrebe dece. Temida, 2010, no. 4, p. 63.

${ }^{3}$ Council of Europe Convention of the Protection of Children against Sexual Exploitation and Sexual Abuse, the Lanzarote Convention (CETS 201), https://rm.coe.int/1680084822, accessed on April $8^{\text {th }}, 2018$. Having been ratified by the required number of states, it came into effect in July 2010.

${ }^{4}$ The Act on the Ratification of the Convention of the Protection of Children against Sexual Exploitation and Sexual Abuse, Official Gazette of the RS - International agreements, no. 1/10.

${ }^{5}$ The Act on Special Measures for Preventing the Commission of Sex Crimes against Minors, Official Gazette of the RS, no. 32/13.

${ }^{6}$ The National Strategy for the Prevention and Protection of Children against Violence, Official Gazette of the RS, no. 122/08.
} 
workplace, as well as mandatory notification about a trip abroad. These special measures remain effective for twenty years after the offender has served the imposed sentence; however, in four-year intervals, the trial court that rendered the first-instance decision is obliged to decide ex officio upon the need for further application of these special measures. Moreover, in two-year intervals from the awarded application date, convicted offenders are allowed to request a revision and reassessment of the further application of these measures by submitting a request to the trial court. Any form of non-compliance with the imposed measures constitutes a misdemeanour offence, which is punishable by a term of 30 to 60 days' imprisonment (Article 16 of the Special Measures Act).

Other issues related to special measures are regulated by the Act on the Execution of Noncustodial Criminal Sanctions and Measures (hereinafter: the Execution Act) ${ }^{7}$ and the Rules on the process of executing non-custodial sanctions/measures, and the organization and activities of the supervision officer (hereinafter: the Rules on the Execution Process). ${ }^{8}$ However, only several articles in the aforementioned acts refer to the execution of special measures. Therefore, the offenders are obliged by law to report personally to a designated supervision officer within the period of three days from the date of the imposed criminal sanction (Article 58 of the Execution Act). The supervision officer's activities are regulated in Articles 59 and 60. First, within the period of three days from the offender's report date, supervision officers must initiate preparatory actions for the execution of special measures and establish cooperation with the police and the professional counseling and treatment institutions which are important for the proper execution of these measures. After that, within the period of eight days from the offender's report date, supervision officers are required to draw up a plan for the execution of special measures, to make the offender aware of the plan and the consequences of non-compliance, and to deliver the plan to the trial court which rendered the first-instance decision, the police and professional counseling service and institutions participating in its execution. Upon the trial court request, supervision officers are also requested to submit a report on the implementation of the execution plan, as well as to inform the competent court within a period of three days about the offender's non-compliance with the special measures. The articles envisaged in the Execution Act are unnecessarily reiterated in the Rules on the Execution Process, which introduces only a small number of specific provisions on the method of implementing the execution plan (Article 36 of the Rules). These provisions include the supervision officers' obligation to assist the offenders through educational and counseling activities so as to make them realize the gravity of their crimes but also to cooperate with members of their families, if necessary. Besides, the parole officer is obliged to inform the court about potential obstacles to the execution of the plan, such as illness of the offender that requires longer treatment or other extraordinary circumstances, which are not explicitly specified in the Execution Act.

\section{Brief Analysis of the Legal Nature of the Special Measures APPLICABLE TO THE PERPETRATORS OF SEX CRIMES AgAINST MinORS}

These special measures have given rise to numerous dilemmas ever since they were first introduced into our legal system. One of the key disputable issues has always been

\footnotetext{
${ }^{7}$ Official Gazette of the RS, no. 55/14.

${ }^{8}$ Official Gazette of the RS, no. 30/15.
} 
the question of their legal nature. Their prominent feature is special prevention, which directly relates them to some other criminal law institutes, particularly to safety measures, which are generally aimed at eliminating the circumstances and conditions that may induce the commission of future criminal offences. ${ }^{9}$ Conditions commonly imply objective factors involved in the commission of crime, whereas the perpetrator's mental state and personal circumstances are subjective factors which, in conjunction with objective factors, lead to the commission of illicit criminal activities. Despite being functionally similar, the basic difference between special measures and safety measures lies in the fact that the latter are ordered by the court, just as all other criminal sanctions, which is not the case with special measures.

Certain similarities are evident when special measures are compared to the legal consequences of conviction, which ensue by the force of law in cases involving specific criminal offences or punishments, and which imply either the cessation or forfeiture of particular rights, or prohibition of acquiring particular rights (Article 94 of the CC). A very simple argument may be used against the endeavours to classify special measures into the category of legal consequences of conviction: namely, the Special Measures Act envisages the legal consequences of conviction as an independent institute. ${ }^{10}$ Therefore, it is not logical to regulate legal consequences of conviction in two different ways within the same legal text: first, by explicitly designating them as such and, second, by concealing them under the term special measures.

Moreover, special measures may also be considered in relation to the obligations pertaining to the framework of protective supervision in cases involving suspended sentences. The protective supervision includes the following obligations: the offender's duty to report to a competent authority in charge of enforcement of protective supervision within periods set by such authority; providing professional training to the offender for a particular profession; the offender's duty to accept employment consistent with his abilities; the obligation to support the family, provide for child care and upbringing, and fulfill other family duties; the duty to refrain from visiting particular places, establishments or events which may provide an opportunity or incentive for re-offending; timely notification of the change of place of residence, address or working place; the duty to refrain from drug and alcohol abuse; treatment in a competent medical institution; visiting particular professional and other counselling centres or institutions and adhering to their instructions; eliminating or mitigating the damage caused by committing the offence, particularly reconciliation with the victim of the criminal offence (Article 73 of the $\mathrm{CC}$ ).

The aforementioned obligations enable the authorities to provide relevant support and assistance to the person who has been awarded a suspended sentence but they also ensure relevant supervision aimed at preventing recidivism (Stojanović, 2017: 324, Lazarević, 2011: 316, Jovašević, 2016: 283), which makes them similar to special measures. It may be concluded, without much mental strive, that the protective supervision obligations and certain special measures are essentially the same in terms of content. For instance, there are striking similarities between the offender's duty to report to a competent authority in charge of enforcement of protective supervision within periods set by the authority and

\footnotetext{
${ }^{9}$ Article 78 of the Criminal Code of Serbia (hereinafter: the CC), Official Gazette of the RS, no. 85/05, 88/05 corr., 107/05 - corr., 72/09, 111/09, 121/12, 104/13, 108/14 u 94/16.

${ }^{10}$ These involve the following: termination of any public function; termination of employment or any kind of job related to work with minors; prohibition of holding any public positions; and prohibition of finding employment in any area related to work with minors.
} 
the obligation of the convicted sex offenders to periodically report to the competent police authority and the Directorate for the Execution of Criminal Sanctions; the offender's duty to refrain from visiting particular places, establishments or events that may provide an opportunity or incentive for re-offending is quite similar to the ban pertaining to sex offenders on visiting places where minors commonly gather for educational, recreational or social purposes; etc. ${ }^{11}$ It may be noted that the language in designating special measures is slightly more stringent, given the fact that the legislator explicitly underscores their mandatory nature; on the other hand, while the obligations stemming from protective supervision measures have not been explicitly designated as "mandatory", which does not imply that the offender is not obliged to perform the imposed obligations. This overlapping might be understood as an attempt to relate new provisions to those that have already been recognized and traditionally practised in our legal system, and thus avoid the criticism against an exaggerated experimentation in the treatment of sex offenders, but also to facilitate the execution of these measures by taking advantage of the experience gained from protective supervision. However, regardless of contextual similarities, it must be argued that protective supervision measures are ordered by the court of law in the form of a judicial decision. Therefore, the only viable response to the posed question concerning the legal nature of special measures may be found in designating them as measures sui generis.

\section{SOME REMARKS ON THE SCOPE OF APPLICATION OF THESE SPECIAL MEASURES}

In principle, when determining the scope of application of these special measures, there is a dilemma whether they shall be applied against all sex offenders or to exclude the perpetrators of minor crimes. The Serbian legislation prescribes these special measures only for adults who commit the following offenses: rape (Article 178, par. 3 and $4 \mathrm{CC}$ ), sexual intercourse with a helpless person (Article 179, par. 2 and $3 \mathrm{CC}$ ), sexual intercourse with a child (Article $180 \mathrm{CC}$ ), sexual intercourse through abuse of position (Article $181 \mathrm{CC}$ ), prohibited sexual acts (Article $182 \mathrm{CC}$ ), pimping and procuring (Article $183 \mathrm{CC}$ ), inducement to prostitution (Article 184, par. $2 \mathrm{CC}$ ), showing, procuring and possession of pornographic materials and abuse of minors for pornography (Article $185 \mathrm{CC}$ ), inducing a minor to be present during sexual intercourse (Article 185a $\mathrm{CC}$ ), and abuse of computer networks or other means of electronic communication with an intent to commit criminal offenses against sexual freedom of minors (Article 185b CC). Envisaged exclusively for the purpose of protecting minors from sexual abuse, the enlisted offenses are classified as sex crimes against minors or qualified forms of general criminal acts involving a minor or a child. ${ }^{12}$

Yet, it has to be noted that this list does not include certain offenses, such as: cohabitation with a minor (Article 190 CC), incest (Article 197 CC) and human trafficking (Article 388 $\mathrm{CC}$ ). Formally, they do not belong to the group of sexual offenses because they are classified as offenses against marriage and family, or offences against humanity and other rights

\footnotetext{
11 Considering that almost each special measure corresponds to some obligation within the protective supervision framework, we may reasonably raise the question concerning the appropriacy of the term which emphasizes their "special" nature.

${ }^{12}$ Serbian legal system states that a minor is an individual of fourteen years of age, but not of eighteen, whereas a child is an individual younger than fourteen years of age (Article 112, par. 8 and $9 \mathrm{CC}$ ).
} 
protected by international law. Cohabitation with a minor becomes a criminal activity if an adult cohabitates with a minor, or if a parent, adoptive parent or guardian enable or induce a minor to cohabitate with another person. The qualified form of this offence exists if the act is motivated by financial gain. The incrimination of cohabitation with a minor provides for legal protection of minors, who are considered to be neither physically nor mentally mature enough to live in such a community, which will only impede their further development, education, etc (Stojanović, 2017: 607). However, besides living together, cohabitation also presupposes sexual relations, which may sometimes entail the likelihood of sexual abuse and exploitation of a minor. Whereas it may be unjustified to claim that every cohabitation with a minor is arranged for this purpose, there is no dispute that such forms of cohabitation do exist. The general definition of cohabitation with a minor and various forms of this criminal offence seem to be the main reason why it has not been included in the aforementioned list. An $a$ priori application of envisaged measures would certainly lead to fairly unjust outcomes considering that they would affect even younger adults living in an extramarital community with older minors, devoid of any ulterior motives but formed with the purpose of either getting married or starting a family, which is quite a common practice among members of some minority groups.

Incest is committed by an adult who engages in sexual intercourse or an act of equal magnitude with an underage relatives of lineal consanguinity or an underage sibling. The sexual abuse is indisputable in all incest cases, notwithstanding the fact that the seriousness of this act is somewhat "diminished" by classifying this offense into the group of offenses against marriage and family. Whereas there may be reasonable grounds for exempting the adult cohabitating with a minor from the application of these special measures, there is hardly any justification for exempting the perpetrators of incest. The incestuous offender who sexually abused a minor relative or next of kin shall not enjoy a more favourable status than other sexual offenders against minors; this argument may be further supported by the fact that some of the sexual offenses that are subjected to the application of special measures are less serious than incest, which is punishable by a term of imprisonment ranging from six months to five years. For example, the prescribed punishment for the basic form of illicit sexual acts is either a fine or a term of imprisonment for up to three years, whereas the criminal act of abusing computer networks or other means of electronic communication with an intent to commit offenses against sexual freedom of minors is punishable by a fine or a term of imprisonment for up to six months (Article 185b, par.1 CC), or a term of imprisonment ranging from three months to three years (Article 185b, par. $4 \mathrm{CC}$ ). The argument for including incest into the group of offences which should be subjected to the application of special measures_may be further supported by the fact that incest is one of the most traumatic experiences that has permanent, lifelong effects on the victim. ${ }^{13}$

When the criminal offence of human trafficking is committed against a minor, it is essential to discern all qualified forms that affect minors as victims (Article 388 paragraphs 2-7 CC), provided that the criminal offence was committed for the purpose of engaging minors in prostitution, sexual exploitation or pornography. The special measures should also apply in case the perpetrator knows or might have known that a minor is a victim of human trafficking and abuses the minor's position or facilitates the minor's abuse by another for the purpose of prostitution, sexual exploitation or

\footnotetext{
${ }^{13}$ For more on the traumatic effects of incest, see: Mršević, Z. Incest između mita i stvarnosti. Institut za kriminološka i sociološka istraživanja i Jugoslovenski centar za prava deteta. Beograd, 1997.
} 
pornography (Article 388, par. $9 \mathrm{CC}$ ). If the legislator had intended to provide more substantial protection of minors, human trafficking should have been classified as one of the sex crimes, particularly given the fact that the majority of underage victims of human trafficking are primarily intended for sexual exploitation.

\section{Discussion of the CONTENTS OF SPECIAL MEASURES, THEIR Potential SPECIAL PREVENTION EFFECTS AND THEIR CRIMINAL POLICY JUSTIFICATION}

The first special measure on the provided list is the obligation of the convicted sex offenders to periodically report to the competent police authority and the Directorate for the Execution of Criminal Sanctions. Within the first 15 days every month, the offender is required to personally report to the police station in the place of residence and to the organizational unit of the Directorate for the Execution of Criminal Sanctions, which is responsible for the correctional treatment and alternative sanctions. A disputable issue arising from measure is the fact that the same reporting regime equally applies to all offenders, without a possibility of being adjusted to specific offenders, irrespective of the gravity of the committed crime or whether they are first-time offenders or re-offenders; generally speaking, the same regime applies to a wide range of perpetrators who differ in terms of the risk of re-offending, which certainly cannot be justified. Moreover, such monolithic use of this special measure is inconsistent with some of the basic criminal law principles: the principles of proportionality and fairness, which should be taken into account in the course of introducing prospective amendments to the Special Measures Act. ${ }^{14}$

The ban on visiting places where minors commonly gather for educational, recreational or social purposes means that offenders are not allowed to visit institutions such as school buildings, school yards, kindergartens, playgrounds, children's festivals and performances, etc. This measure is a based upon the theory of routine activities, which presupposes that criminal activities result from the coordination of several factors: a motivated perpetrator, the encounter with a victim, and the absence of the "guardian" who can provide adequate protection (Cohen, Felson, 1979: 588-608). In crime control, this can be realized by eliminating the motivated offender from the places frequented by prospective victims, by forming the so-called hot spots, i.e. the places generally frequented by a large number of minors, and occasionally the so-called buffer zones, which are additional protective belts around the hot spots. The basic disadvantage of this measure is the lack of rules on the way of executing this measure and its supervision. The Special Measures Act, the Execution Act, and the Rules on Execution Process contain no single provision on this matter. In the comparative law, the compliance with the prohibition of visiting particular places is monitored by the use of the GPS system (Maloy, Coleman, 2009: 245, Shekhter, 2010: 1086-1087, Wright, 2008: 36). However, this solution has been the subject matter of considerable dispute, ultimately leading to the judicial review on the constitutionality of

\footnotetext{
${ }^{14}$ The graded application of this measure can be illustrated by several examples from the comparative law. In Macedonia, the offenders are required to report to the court in their place of residence at least once a year, five days prior to their birthday, until the end of their lives; see Article 7 of the Act on the Special Register of Sexual Offenders convicted of sexual abuse of minors and pedophilia, Official Gazette of the Republic of Macedonia, no. $11 / 12$ u 112/14. In the USA, the offenders must report to the police in person once a year, once in six months or once in three months, depending on the specific category of sex offenders (who are classified into three tiers); see Section 116 of Adam Walsh Act (2006) at http://www.justice.gov/olp/pdf/adam_walsh_act.pdf; assessed on April $8^{\text {th }}, 2018$.
} 
using the GPS system for tracking sex offenders (Shekhter, 2010: 1091-1094); the results of some empirical studies have contributed to raising doubt in the efficiency of this form of supervision of sex offenders (Finn, Muirhead-Steves, 2002: 305-307, Maloy, Coleman, 2009: 247). The problem in our country is definitely the lack of technical equipment in the supervising services as well as the cost of applying this type of supervision.

In addition, the ban on visiting places where minors commonly gather is based on the hypothesis that the sex offender is the so-called "dangerous stranger" who lurks in places where minors frequently gather in great numbers. Yet, research on the phenomenology of this kind of criminal offenses in Serbia offers quite a different view. According to a study conducted in Serbia from 1994 to 1998, the victims knew the sex offenders in $98.2 \%$ of all cases. This result was confirmed in another study conducted in the period from 2004 to 2009, but the percentage was even higher, given the fact that all the victims had already known their offenders (Petković, Đordjević, Balos, 2010: 312). When correlated with the obtained results, there is a dilemma whether this measure can contribute to achieving the desired preventive effect, particularly considering that it was created for a completely different type of offender as compared to the statistically most prominent type of sex offenders in Serbia, which often includes family members, friends, relatives, neighbors, and other individuals known to the victims.

Mandatory counseling in professional counseling centers and institutions implies that the offenders are required to comply with this measure and get professional assistance in accordance with the plan determined by the organizational unit of the Directorate for the Execution of Criminal Sanctions, which is in charge of the offenders' treatment and alternative sanctions. Unlike other measures, which are mainly aimed at supervision and control, this special measure reflects a propensity to help the offender. It may contribute to changing the offender's attitudes towards the committed crime, raising awareness about the socially unacceptable forms of behaviour, and developing empathy towards the victims. This form of intervention may also have some effect on the control of the aggressive and impulsive behavior, for example, through cognitive-behavioral therapy. The greatest drawback are the poor technical capacities for the application of this measure. Namely, there are no provisions on the institutions that are to implement this measure. The situation in Serbia is further aggravated by the fact that there is an evident lack of highly qualified experts, well-trained and experienced staff, and special standardized programmes for the treatment of sex offenders. This is actually part of a much broader problem related to the procedure on the execution of prison sentences. In Serbia, various programmes are developed and applied to drug addicts or perpetrators of violent but non-sexual crimes; for the aforesaid reasons, ${ }^{15}$ such programs are not applied in the institutional treatment of sex offenders.

Mandatory notification of any change concerning the place of residence, habitual stay or workplace means that the offenders are required to personally inform the competent organizational unit of the police and the organizational unit of the Directorate for the Execution of Criminal Sanctions, which is responsible for the offender's treatment and alternative sanctions, within the period of three days from the change date. There is a similar measure in the comparative law, but it is particularly interesting that some legislations include different consequences of non-compliance with this measure. In the

\footnotetext{
${ }^{15}$ More in: Radojković, Z., Petković, N., Potrebe i mogućnosti tretmana učinilaca krivičnih dela protiv polnih
} sloboda - Belgrade School of Defectology, 2017, vol. 23, no. 2, p. 74-76. 
Serbian legal system, the failure to observe the imposed measure is regarded as a misdemeanour, and punished accordingly. In some legal systems, if the periodic supervision proves that the offender cannot be located at the registered address, the police is allowed to put the offender on the wanted list and enter his names into the wanted persons database. ${ }^{16}$ This mechanism seems to offer a more efficient control and protection, and it is a very significant deterrent to crime.

Mandatory notification of the trip abroad means that the offender is required to report in person to the designated organizational unit of the police at least three days prior to the journey. The information should contain the name of the country of travel, the place and length of stay abroad. This obligation is present in many comparative legal systems but the offender may be required to provide much more detailed information on the trip. ${ }^{17}$ The additional aim of this measure is to establish international cooperation in the area of counteracting sex crimes which is impossible to accomplish without the exchange of relevant data about sex offenders. The introduction of this measure might have been the result of the conclusion that the modus operandi of some offenders entails a trip abroad for the purpose of committing a crime and the emergence of the new phenomenon of sex tourism, where pedophiles visit destinations renowned for child prostitution. ${ }^{18}$ As for the application of this special measure, it has to be noted that the aforementioned modus operandi is not a typical feature and common practice of sex offenders in Serbia.

\section{CONCLUDING REMARKS}

The introduction of special measures for sex offenders who commit crimes against minors is probably approved by the general public, although the results of scarce empirical studies emphasize that more repressive measures would also enjoy public support, given that the respondents were in favor of more stringent prison sentences, chemical castration, and even death penalty. ${ }^{19}$ On the other hand, as stated upon the adoption of this Act, the legislator has high expectation from these special measures,

\footnotetext{
${ }^{16}$ In French legislation, for example, registered offenders are required to confirm their home address once a year and to report any change of home address within a period of fifteen days from the date of respective change, which may be done either via registered mail with acknowledgment of receipt or by reporting to the police or the prosecution office. However, the perpetrators of serious crimes, sentenced to over ten years' imprisonment, are required to report in person and have their data checked more frequently, usually once in six months or every month in cases involving very dangerous offenders. In case of non-compliance with this obligation, the prescribed punishment is a two-year term of imprisonment and a fine of 30,000 Euros, alongside with the aforesaid additional mechanism. See Articles 706-53-5 and 706-53-8 Code de procedure pénale, with the latest amendments of 2016; http://www.legislationline.org/documents/section/criminal-codes, assessed on $8^{\text {th }}$ April 2018.

${ }^{17}$ For example, in Great Britain, the information on the trip abroad has to include: the departure date, the name of the country of travel (if the trip covers more than one country, the person enters only the name of the country that is to be visited first), the place of arrival, the return date, and other information concerning the departure from and arrival in Great Britain, as well as information about other activities abroad. See Article 86, Sexual Offences Act, 2003 (with latest amendments of 29 ${ }^{\text {th }}$ May 2012), http://www.legislation.gov.uk/ukpga/2003/42/ section/86; assessed on $8^{\text {th }}$ April 2018.

${ }_{18}$ Commercial sexual exploitation of children is mostly prominent in Asia (especially in Thailand, the Philippines and India) but also in many African countries; it has become a serious problem in some Eastern Europe countries in the post-communist period. More in: Konstantinović-Vilić, S., Nikolić-Ristanović, V., Kostić, M., Kriminologija, Niš 2009, p. 146.

${ }^{19}$ More in: Petković, N., Đordjević, M., Balos, V. Op. cit, p. 74.
} 
which are supposed to be more efficient than the sanctions formerly applied to sex offenders. However, in the countries where these special measures have been in effect for decades, there are different opinions on the actual effects of these measures. Some authors emphasize that it has not yet been proven that they have a significant impact on reducing criminal recidivism and increasing safety in the community (Levenson D'Amora: 2007, 168-199); some authors think that they are not effective at all in the context of sexual abuse and exploitation of minors within the family and among friends (Long, 2009: 161), while others consider them to be counterproductive (Wakefield, 2006: 141-149).

At present, it is still not possible to write about some experiences in Serbia, considering the fact that the Act on Special Measures for Preventing the Commission of Sex Crimes against Minors was adopted in 2013, and that there is still a lack of relevant empirical data for a more comprehensive assessment. On the other hand, this theoretical analysis has indicated certain problems. The catalogue of envisaged special measures is partly incompatible with the phenomenological characteristics of this type of crime in Serbia, which further implies that their special prevention effects and criminal policy justification remain disputable. The limiting factors in certain cases are the insufficiently defined execution procedure, the lack of technical equipment needed for supervision, and the lack of highly trained experts and special standardized programmes for sex offenders' treatment. The designated supervision offices in charge of the execution of these special measures still cannot adequately address the posed challenges and meet all the requirements for their effective application. The results of research conducted among supervision officers clearly show that their complaints mainly focus on the lack of employees and technical staff, a huge caseload, poorly organized network of supervision offices which cannot exercise relevant control over the offenders, and the lack of technical equipment (Spasojević, Arsenijević 2017: 28). Therefore, it can be concluded that the legislator may have acted a bit hastily when deciding to pass the Special Measures Act, but it was done for two reasons: to fulfill the obligations arising from the ratification of the Convention on the Protection of Children against Sexual Exploitation and Sexual Abuse Convention, and to calm down the general public justifiably revolted by several tragic cases of sexual abuse of minors with fatal outcomes. ${ }^{20}$ Thus, Serbia has experienced the same "scenario" as many other countries: whenever minors are victims of sexual abuse, the subjective and sensationalist media reporting combined with the widespread "panic" among citizens results in the strengthening the instruments of criminal law repression by introducing inadequate measures of disputable efficiency. In that context, the adopted legal solutions should be definitely reassessed and revised in order to create a more logical and efficient protection system. This is probably the right time for such an action in the Republic of Serbia, particularly given the fact that the National Strategy on the Prevention and Protection of Children against Violence for the period 2018-2022 is currently being drafted.

\footnotetext{
${ }^{20}$ The Special Measures Act is also known as "Marija's Act", named after Marija Jovanović, an eight-year-old girl who was raped and murdered by the sex offender who had been previously convicted for sexual offenses against minors. The initiative came from the girl's father for purpose of preventing similar crimes in the future.
} 


\section{REFERENCES}

Act on the Execution of Non-custodial Criminal Sanctions and Measures Official Gazette of the RS, no. 55/14. Act on the Ratification of the Convention of the Protection of Children against Sexual Exploitation and Sexual Abuse, Official Gazette of the RS - International agreements, no. 1/10.

Act on Special Measures for Preventing the Commission of Sex Crimes against Minors, Official Gazette of the $R S$, no. $32 / 13$.

Act on the Special Register of Sexual Offenders convicted of sexual abuse of minors and pedophilia, Official Gazette of the Republic of Macedonia, no. 11/12, 112/14.

Adam Walsh Act (2006), http://www.justice.gov/olp/pdf/adam_walsh_act.pdf; assessed on April $8^{\text {th }}, 2018$.

Code de procedure pénale (with the latest amendments of 2016); http://www.legislationline.org/documents/ section/criminal-codes, assessed on $8^{\text {th }}$ April 2018.

Cohen, L. E., Felson, M. (1979). Social Change and Crime Rates: A Routine Activities Approach. American Sociological Review, no. 44, pp. 588-608.

Council of Europe Campaign One in Five: The Council of Europe Campaign to Stop Sexual Violence Against Children, accessible at http://www.coe.int/t/DG3/children/1in5/default_en.asp, accessed on April $8^{\text {th }}, 2018$.

Council of Europe Convention of the Protection of Children against Sexual Exploitation and Sexual Abuse, the Lanzarote Convention (CETS 201), https://rm.coe.int/1680084822, accessed on April $8^{\text {th }}, 2018$.

Criminal Code of Serbia, Official Gazette of the RS, no. 85/05, 88/05 - corr., 107/05 - corr., 72/09, 111/09, 121/12, 104/13, 108/14 u 94/16.

Finn, M. A., Muirhead-Steves, S. (2002). The Effectiveness of Electronic Monitoring with Violent Male Parolees. Justice Quarterly, vol. 19, iss. 2, pp. 293-312.

Jovašević, D. (2016). Krivično pravo, Opšti deo. Beograd: Dosije

Konstantinović-Vilić, S., Nikolić-Ristanović, V., Kostić, M. (2009). Kriminologija, Niš: Pravni fakultet

Levenson, J. S., D'Amora, D. H. (2007). Social Policies Designed to Prevent Sexual Violence: The Emperor's New Clothes. Criminal Justice Policy, vol. 18, no. 2, pp. 168-199.

Long, A. (2009). Sex Offender Laws of the United Kingdom and the United States: Flawed Systems and Needed Reforms. Transnational Law and Contemporary Problems, vol. 18, pp. 145-166.

Lazarević, Lj. (2011). Komentar Krivičnog zakonika, drugo izmenjeno i dopunjeno izdanje. Beograd: Pravni fakultet Union

Maloy, M. L., Coleman, S. (2009). GPS Monitoring of Sex Offenders. In: Wright, R. Sex Offender Laws, Failed Policies, New Directions: Springer, pp. 243-266.

Mršević, Z. (1997). Incest između mita i stvarnosti. Beograd: Institut za kriminološka i sociološka istraživanja i Jugoslovenski centar za prava deteta

National Strategy for the Prevention and Protection of Children against Violence, Official Gazette of the RS, no. $122 / 08$.

Petković, N., Đorđević, M., Balos, Đ. (2010). Analiza stavova javnosti u Srbiji prema fenomenu seksualne zloupotrebe dece, Temida, no. 4, 2010, pp. 61-82.

Radojković, Z., Petković, N. (2017). Potrebe i mogućnosti tretmana učinilaca krivičnih dela protiv polnih sloboda. Belgrade School of Defectology, vol. 23, no. 2, pp. 71-90.

Rules on the process of executing non-custodial sanctions/measures, and the organization and activities of the supervision officer, Official Gazette of the RS, no. 30/15.

Sexual Offences Act (with latest amendments of $29^{\text {th }}$ May 2012), http://www.legislation.gov.uk/ukpga/2003/ 42/section/86; assessed on $8^{\text {th }}$ April 2018.

Shekhter, S. (2010). Every Step You Take, They'll Be Watching You: The Legal and Practical Implications of Lifetime GPS Monitoring of Sex Offenders. Hastings Constitutional Law Quarterly, vol. 38, no. 4, pp. 1085-1112.

Spasojević, A., Arsenijević, S. (2017). Efekti alternativnih sankcija i mera iz ugla povereničke službe, Valjevo: Odbor za ljudska prava

Stojanović, Z. (2017). Komentar Krivičnog zakonika, šesto izmenjeno i dopunjeno izdanje. Beograd: Službeni glasnik

Wakefield, H. (2006). The Vilification of Sex Offenders: Do Laws Targeting Sex Offenders Increase Recidivism and Sexual Violence? Journal of Sexual Offender Civil Commitment: Science and the Law, no. 1, pp.141-149.

Wright, R. G. (2008). Parole and Probation: Sex Offender Post-Incarceration Sanctions: Are There Any Limits? New England Journal on Criminal and Civil Confinement, vol. 34, no. 1, 2008, pp. 17-50. 


\title{
POSEBNE MERE ZA SPREČAVANJE VRŠENJA KRIVIČNIH DELA PROTIV POLNE SLOBODE PREMA MALOLETNICIMA - PRIMER SRBIJE -
}

\begin{abstract}
Konvencija o zaštiti dece od seksualnog zlostavljanja i seksualnog iskorišćavanja je ratifikovanjem postala deo našeg pravnog poretka, čime je i nastala obaveza da se različite mere koje predviđa u cilju suzbijanja ovog oblika kriminaliteta detaljnije urede, što je i ostvareno donošenjem Zakona o posebnim merama za sprečavanje vršenja krivičnih dela protiv polne slobode prema maloletnim licima. Ovaj rad predstavlja pokušaj da se detaljnije prouče tzv. posebne mere za sprečavanje dela protiv polne slobode prema maloletnicima, sa posebnim osvrtom na pojedina sporna pitanja.
\end{abstract}

Ključne reči: seksualni delikti, maloletnici, posebne mere za sprečavanje krivičnih dela protiv polne slobode.

Proofreading:

Gordana Ignjatović 